\title{
ПРАВОВОЙ МЕХАНИЗМ ВЗАИМОДЕЙСТВИЯ ОБЩЕСТВЕННЫХ ПАЛАТ СУБЪЕКТОВ РОССИЙСКОЙ ФЕДЕРАЦИИ С ОРГАНАМИ ГОСУДАРСТВЕННОЙ ВЛАСТИ РОССИЙСКОЙ ФЕДЕРАЦИИ И МЕСТНОГО САМОУПРАВЛЕНИЯ
}

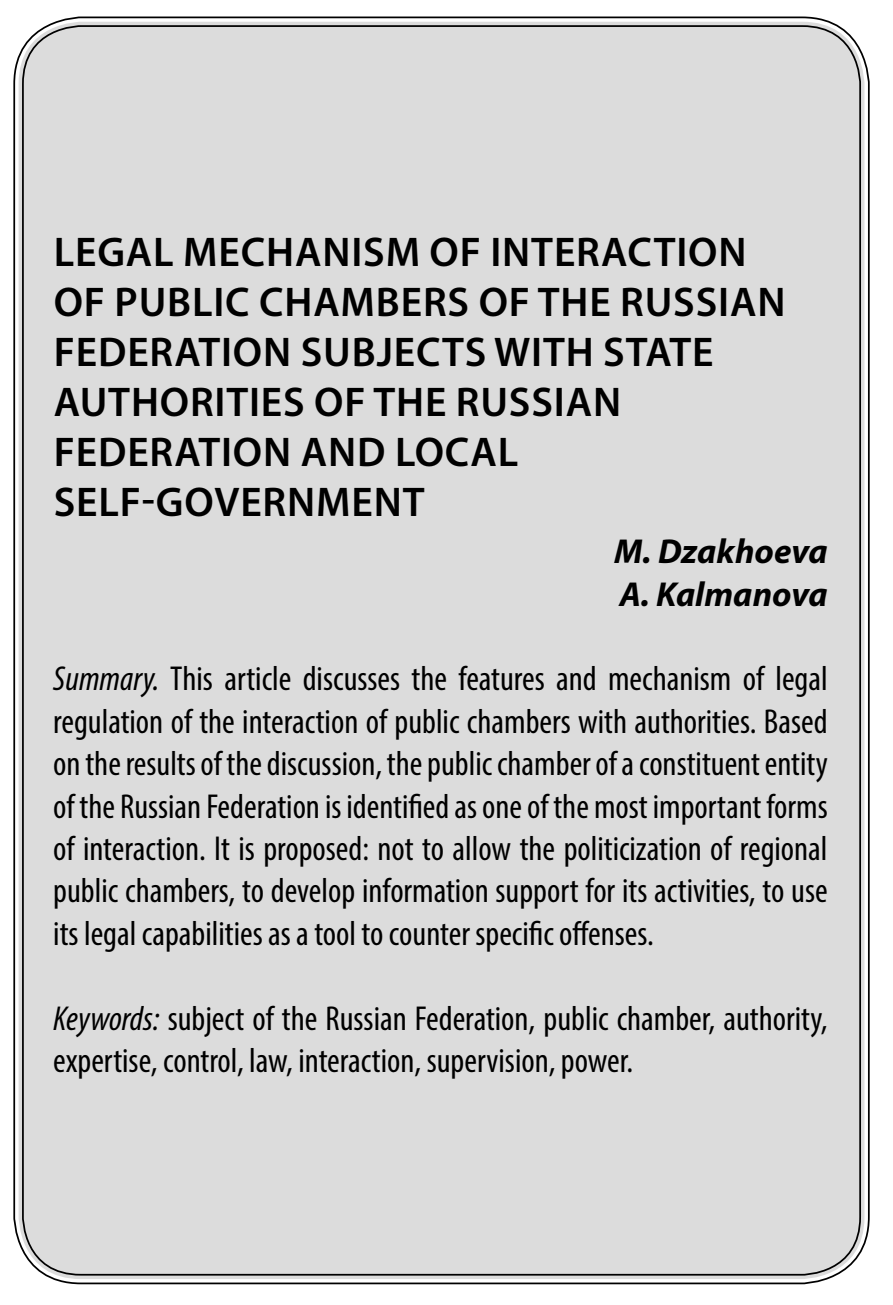

3 начимыми критериями оценки деятельности органов государственной власти и местного самоуправления выступают: 1 - своевременное выявление допущения нарушений законодательства, и, что немаловажно, 2 - точное понимание современных общественных запросов. Полагаем, что последний посыл оказал существенное влияние на создание Общественной палаты.

Общественная палата Российской Федерации не наделяется властными полномочиями, что указано в федеральном законе от 04.04.2005 N32-Ф3 «Об Общественной палате Российской Федерации» [2] (далее-Закон), и это,
Дзахоева Марина Валерьевна

Аспирант, Северо-Осетинский государственный университет имени К.Л. Хетагурова dzahoeva-larisa@rambler.ru

Калманова Альбина Сослановна

К.ю.н., доцент, Северо-Осетинский государственный университет имени К.Л. Хетагурова

Аннотация. В настоящей статье рассмотрены особенности и механизм правового регулирования взаимодействия общественных палат с органами власти. По итогам рассмотрения темы общественная палата субъекта РФ определена как одна из важнейших форм взаимодействия. Предложено: не допускать политизацию региональных общественных палат, развивать информационное обеспечение ее деятельности, применять ее правовые возможности как инструмент противодействия конкретным правонарушениям.

Ключевые слова: субъект РФ, общественная палата, полномочия, экспертиза, контроль, закон, взаимодействие, надзор, власть.

безусловно, соответствует государственной позиции о социально-правовом характере данного института.

В настоящее время общественные палаты в субъектах Российской Федерации выступают координирующими центрами общественной активности. Их взаимодействие с органами государственной власти РФ и местного самоуправления осуществляется по самым различным направлениям, рассмотрим некоторые из них.

Одним из вариантов взаимодействия общественных палат с органами государственной власти является взаимодействие с общественными советами, функциониру- 
ющими при законодательных органах государственной власти субъектов РФ, включая их систематическую информационную, методическую и иную поддержку.

В результате анализа регионального законодательства можно выделить такие формы участия общественной палаты в формировании общественного совета, как:

1. согласование правового статуса совета;

2. выступление с инициативой о формировании общественного совета;

3. организация, а также непосредственное участие в конкурсном отборе кандидатур членов общественного совета;

4. выдвижение и согласование кандидатур в состав общественного совета;

5. утверждение состава общественного совета.

Типовое положение, закрепляющее статус общественного совета при региональном высшем органе исполнительной власти, утверждается, соответственно, правительством (администрацией) конкретного региона. Нормативный правовой акт, определяющий статус общественного совета при региональном исполнительном органе (министерстве, департаменте, комитете, управлении), разрабатывается, как правило, самим органом и утверждается его руководителем. В отдельных регионах предусматривается его согласование с общественной палатой, что прослеживается, к примеру, из законодательства Республики Хакасия [3] и Кабардино-Балкария [4].

Общественные советы формируются, как правило, путем проведения конкурса, который организуется органом государственной власти. При этом, необходимо отметить, что степень участия общественных палат в процедурах создания общественных советов в каждом регионе существенно различается. Так, в Тамбовской области существует практика, согласно которой представители Общественной палаты подлежат включению в состав конкурсной комиссии. В свою очередь, в Новгородской области из семи членов комиссии по отбору кандидатов в Общественный совет не менее половины должны составлять представители общественной палаты и общественных организаций. В Амурской, Курганской, Оренбургской областях Общественные палаты сами выступают в качестве организаторов конкурса.

Кроме этого, общественные палаты правомочны предлагать региональным органам исполнительной власти формирование общественного совета, что, к примеру, следует из законодательства Кабардино-Балкарской Республики [4].

Далее, отметим, что реализация направлений деятельности общественных палат в регионах требует определенных форм фиксации методов правового регулирования. Согласно положениям Закона, надлежащее выполнение задач достигается, в том числе, и работой по выработке рекомендаций для органов государственной власти. Названные правовые инструменты предоставляют обществу достаточные возможности для создания социально-политических единиц, которые в свою очередь наделены полномочиями исключительно рекомендательного характера, что предполагает только опосредованное их участие в общественном контроле.

Раскрывая содержание общественного контроля, важно не отождествлять его с функцией надзора. Так, согласно позиции Т.В.Троицкой, «общественный контроль как направление деятельности общественной палаты субъекта РФ не соответствует сущностной стороне своего содержания и требует замены на понятие «общественный надзор» [10. С. 9].

Но такая ротация, по нашему мнению, представляется некорректной и снижает результативность контрольной деятельности общественных палат. Известно, что правовая природа надзора - это постоянное, систематическое наблюдение специальным субъектом за деятельностью не подчиненных ему органов, организаций или же конкретных лиц, которая направлена на своевременное выявление нарушений законов. При этом деятельность поднадзорных субъектов оценивается исключительно с точки зрения законности, а вопросы о целесообразности, экономичности, качестве не учитываются, как, впрочем, и иные критерии, характеризующие эффективность работы субъекта РФ. Исходя из этого, именно контроль связан с осуществлением общественных функций.

Полагаем, что под контрольной деятельностью следует понимать систему мероприятий, основным направлением которых является как выявление и пресечение нарушений, так и повышение эффективности деятельности подконтрольных субъектов. Поэтому через контроль обеспечивается объективная оценка существующей ситуации и создаются предпосылки для того, чтобы были внесены необходимые коррективы деятельности проверяемого органа. Вследствие чего считаем целесообразным законодательное разграничение рассматриваемых понятий: надзор должен быть отнесен к компетенции органов государственной власти, а контроль - к ведению общественных структур (в качестве функции внешнего аудита).

Следует отметить, что правовое регулирование вопроса определения объема полномочий общественных палат субъектов РФ в области осуществления контроля закреплено в Федеральном законе от 21 июля 2014 г. N212-Ф3 «Об основах общественного контроля в Российской Федерации» [1]. В ч. 1 ст. 4 вышеуказанного фе- 
дерального закона определено, что общественный контроль - это деятельность его субъектов по наблюдению за органами власти, общественной проверки, анализа и общественной оценки соответствующих актов и решений.

То есть, общественными палатами регионов выполняется, в том числе, функция наблюдения за процессами, происходящими в государстве. Вышеуказанная правовая норма ч. 1 ст. 4 Федерального закона N212-Ф3 выделяет и закрепляет такой признак общественного контроля, как его непосредственность. Однако названная в данной статье цель в большей мере выступает как правовой инструмент, используемый для достижения результата.

На фоне встречающихся в исследованиях характеристик общественного контроля, тем не менее, отсутствуют те, которые позволяли бы реализовывать те цели и задачи общественных палат субъектов РФ, ради которых они создавались. Например, защищать права и свободы. Учитывая это, не совсем ясно, как субъект контроля, не имея возможности оказывать воздействие на процесс, т.е. быть непосредственным участником правоотношения, в рамках которого осуществляется наблюдение или оценка работы, может вообще его контролировать.

Так, например, общественная палата не имеет полномочий проводить самостоятельную проверку деятельности федеральной службы исполнения наказаний. И, как следствие, у нее нет возможности выявлять нарушения прав и свобод осужденных, осуществляя функцию общественного контроля деятельности органов государственной власти. Подобные нарушения, если они были допущены и если их и не пытались скрыть, могут остаться незамеченными. Однако описанный нами правовой риск не допустим, тем более, когда речь идет о судьбе человека. Поэтому авторы разделяют мнение профессора В.В.Гриб о том, что общественная палата должна обладать такой функцией общественного контроля как проверка [7. С. 7]. Считаем, что, для того чтобы отработать механизмы общественного контроля, целесообразно их использовать в конкретных сферах деятельности органов государственной власти.

Как, верно обосновывает Р.В. Прудентов, это особенно важно там, где «власть государственного служащего, ответственного за распределение заказов на покупку товаров или оказание услуг для государства (соответствующей организации) - от покупки мелких канцелярских принадлежностей до оказания многомиллиардных подрядных услуг» [9. С. 37].

В этой связи для максимально эффективного и «прозрачного» освоения государственного бюджета зако- нодательно следовало бы закрепить обязательность общественного контроля в области проведения закупок до момента заключения государственного контракта. То есть, в данном случае важно проводить проверку поданных участниками аукциона заявок, выбора контрагента, выполнения обязательств и т.д. С учетом изложенного, полагаем, что проверка, являясь одной из форм непосредственного контроля, имеет своей целью установление соответствия или несоответствия предмета проверки требованиям закона. Указанные полномочия могут иметь и органы государственной власти, и органы местного самоуправления.

Таким образом, выступая в качестве правового механизма реализации контрольно-надзорных функций, проверка включает в себя определенные правовые конструкции, к которым следует относить:

- доступ к документам объекта контроля;

- изъятие и экспертиза предметов проверки;

- подготовка заключений и т.д.

Вместе с тем мы согласны с председателем Общественной палаты Республики Марий Эл Т.Н. Михеевой, которая полагает, что на сегодняшний день нет достаточных правовых оснований для полноценного участия граждан в мероприятиях общественного контроля и снятия административных барьеров для активной деятельности [8. С. 37].

Очевидно, что для дальнейшего развития рассматриваемого института необходима систематизация нормативных правовых актов об общественном контроле. Это позволит разработать единую и четкую систему стандартов о содержании понятия общественного контроля, его объекте, предмете, субъектах, целях, принципах, формах, методах, средствах и т.д. В противном случае действующие общественные палаты в субъектах могут рассматриваться скорее, как совещательные органы.

Еще один вид деятельности общественных палат регионов - это общественная экспертиза проектов правовых актов органов государственной власти и местного самоуправления. Это следует, например, из п. 3 ст. 2 закона Республики Ингушетия «Об Общественной палате Республики Ингушетия», согласно которому общественная экспертиза проводится рабочей группой, а сам порядок проведения устанавливается в локальном акте общественной палаты. Экспертами в данном случае могут быть как некоммерческие организации, так и физические лица. Аналогичные положения содержатся в законодательстве Республики Дагестан [5], Карачаево-Черкесской Республики [6] и др.

Аппарат общественной палаты отвечает за деятельность рабочих групп в части организационно-техниче- 
ского и информационного обеспечения. Результатом экспертизы является сводное экспертное заключение, носящее рекомендательный характер.

Исходя из вышеизложенного можно сделать следующие выводы.

1. Общественная палата субъекта РФ является одной из основных форм взаимодействия общественных объединений и государственных, муниципальных органов власти.

2. В настоящее время очень актуален вопрос разработки мероприятий, повышающих эффективность контрольных механизмов в деятельности общественных палат субъектов РФ, в действующем законодательстве.

3. В целях реализации возложенных на общественные палаты задач считаем целесообразным:

- закрепить на законодательном уровне формы непосредственного общественного контроля, ме- ханизмы осуществления и их реализацию за общественной палатой;

- исключить возможность излишней политизации общественной палаты во избежание сращивания с госаппаратом и, как следствие, утраты независимого контроля;

- активно информировать общественность о деятельности общественной палаты, в том числе о выявленных нарушениях;

- использовать правовые возможности общественной палаты как инструмента противодействия определенным составам правонарушений (к примеру, коррупционной направленности).

Таким образом, совершенствование деятельности общественных палат субъектов РФ будет способствовать их более эффективной деятельности и формированию реального партнерства общества, государства и личности во всех сферах взаимодействия.

\section{ЛИТЕРАТУРА}

1. Федеральный закон от 21.07.2014 N212-Ф3 (ред. от 27.12.2018) «06 основах общественного контроля в Российской Федерации» // Собрание законодательства РФ. 2014. N30 (Часть I). (т. 4213.

2. Федеральный закон от 04.04.2005 N32-Ф3 (ред. от 05.12.2017) «06 0бщественной палате Российской Федерации» // Собрание законодательства РФ. 2005. N15. С. 1277.

3. Закон Республики Хакасия от 14.02.2017 N02-3PX «06 0бщественной палате Республики Хакасия» (принят BC PX 08.02.2017) // Вестник Хакасии. N12. 14.02.2017.

4. Закон Кабардино-Балкарской Республики от 08.06.2009 N26-Р3 «0б Общественной палате Кабардино-Балкарской Республики» (принят Парламентом КБР 29.04.2009) // Официальная Кабардино-Балкария. 27. 12.06.2009.

5. Закон Республики Дагестан от 17.10.2006 N48 (ред. от 08.06.2018) «06 0бщественной палате Республики Дагестан» (принят Народным Собранием РД 28.09.2006) // Дагестанская правда. N267-268. 2006.

6. Закон Карачаево-Черкесской Республики от 17.05.2011 N27-P3 (ред. от 30.12.2019) «0б Общественной палате Карачаево-Черкесской Республики» (принят Народным Собранием (Парламентом) КЧР 29.04.2011) // День Республики. N97-98(18238). 2011.

7. Гриб В. В. Актуальные проблемы правового развития института общественного контроля в Российской Федерации // Конституционное и муниципальное право. 2015. N11.C. 7.

8. Михеева Т.Н. И снова об общественном контроле: грядущие новации законодательства // Конституционное и муниципальное право. 2017. N. С. 37.

9. Прудентов Р. В. Общественный контроль как инструмент противодействия коррупции // Конституционное и муниципальное право. 2016. N10. С. 37.

10. Троицкая Т. В. Конституционно-правовой статус общественной палаты субъекта Российской Федерации (на опыте Приволжского федерального округа): Автореф. дис. ... канд. юрид. наук. Саратов, 2007. С. 9.

(c Дзахоева Марина Валерьевна ( dzahoeva-larisa@rambler.ru ), Калманова Альбина Сослановна. Журнал «Современная наука: актуальные проблемы теории и практики» 